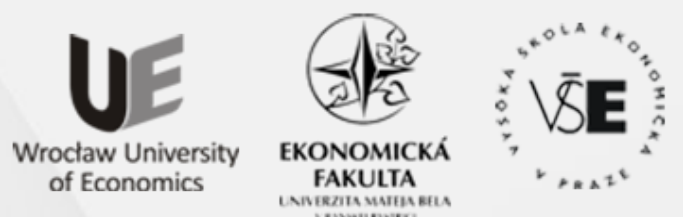

Conference Proceedings

Full TeXT PAPERS

edited by

Zofia Rusnak and Beata Zmyślona

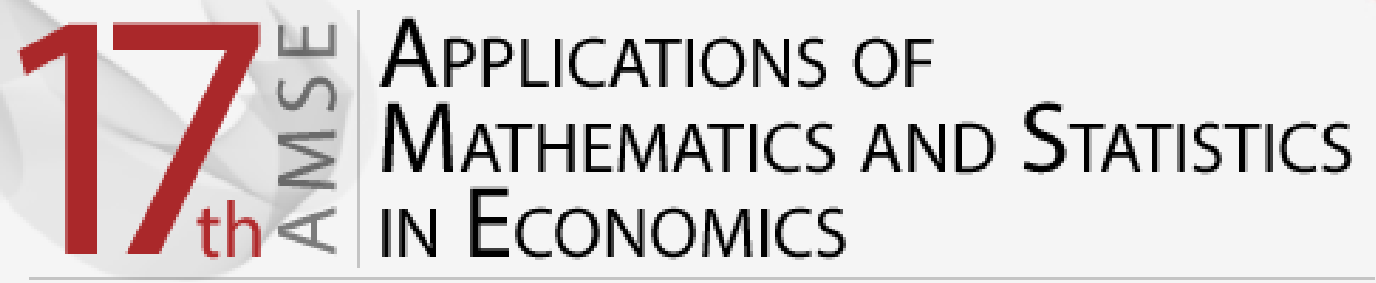

International Scientific Conference | Poland • 27-31 August 2014 
Scientific Committee

Richard Hindls, Stanislava Hronová, Rudolf Zimka, Walenty Ostasiewicz, Emília Zimková, Zofia Rusnak, Martin Bod'a

Organizing Committee

Beata Zmyślona, Cyprian Kozyra, Grzegorz Rogoziński, Kristýna Vltavská

\section{Reviewers}

Milan Bašta, Diana Bílková, Martin Bod'a, Joanna Dębicka, Tomáš Fiala, Jakub Fischer, Stanisław Heilpern, Karel Helman, Lenka Hudrlíková, Miroslav Hužvár, Nikola Kaspř́ková, Alena Kaščáková, Kamil Kladívko, Jindřich Klůfa, Pavol Král', Katarzyna Kuziak, Jana Langhamrová, Ivana Malá, Tomáš Marcinko, Luboš Marek, Miloš Maryška, Petr Mazouch, Zofia Mielecka-Kubień, Witold Miszczak, Petr Musil, Gabriela Nedelová, Walenty Ostasiewicz, Iva Pecáková, Viera Roháčová, Zofia Rusnak, Mária Stachová, Jana Špirková, Šárka Šustová, Jana Tepperová, Vladimír Úradníček, Kristýna Vltavská, Michal Vrabec, Dariusz Wawrzyniak, Henryk Zawadzki, Jaroslav Zbranek, Tomáš Zeithamer, Martin Zelený, Jan Zeman, Rudolf Zimka, Emília Zimková, Pavel Zimmermann, David Žižka

Layout

Martin Bod'a, Beata Zmyślona, Grzegorz Rogoziński

Front page design

Grzegorz Rogoziński

CD cover design

Beata Dębska

Articles published in the form submitted by the authors

All rights reserved. No part of this book may be reproduced in any form or in any means without the prior permission in writing of the Publisher

(C) Copyright by Wrocław University of Economics Wrocław 2014

ISBN 978-83-7695-421-9

Wydawnictwo Uniwersytetu Ekonomicznego we Wrocławiu

53-345 Wrocław, ul. Komandorska 118/120 www.ue.wroc.pl

Sprzedaż książek tel./fax 71 36-80-602

e-mail: econbook@ue.wroc.pl www.ksiegarnia.ue.wroc.pl 


\section{Contents}

Foreword

Diana Bílková: TL-Moments: Analogy of Classical L-Moments

Dagmar Blatná: Application of Robust Regression in the Analysis of Internet Access in European Countries

Martin Bod’a, Mária Kanderová: Rebalancing Issues in Tracking Error Variance Minimization

Martin Bod'a, Viera Roháčová: Application of Six Sigma Ideas to Timing Decisions at Financial Markets

Anton Dekrét, Rudolf Zimka: On the Price Hartwick's Task and Its Inverse in a Dynamic Model of an Economy with Exhaustible Resources

Joanna Dębicka, Agnieszka Marciniuk: Comparison of Reverse Annuity Contract and Reverse Mortgage on the Polish Market.

Petra Dotlačilová, Jitka Langhamrová: The Influence of Mortality Models for the Expected Future Life-time of Older People

Marek Ďurica, Lucia Švábová: Delta and Gamma for Chooser Options.

Vlastimil Farkašovský: New Concept of Pension Funds Performance Evaluation

Albert Gardon: The Normality of Weekly Relative Changes of the Freight Rate in Container Shipping.

Mária Grausová, Miroslav Hužvár, Jana Štrangfeldová: Healthcare Systems Efficiency in the Visegrád Group.

Stanisław Heilpern: Multiple Life Insurance - Pension Calculation

Alena Kaščáková, Gabriela Nedelová: Changes in Slovak Households' Economy

Igor Kollár, Pavol Král', Peter Laco: Methodology for Assessing Website Improvement in Corporate Environment.

Maciej Kostrzewski: Some Method of Detecting the Jump Clustering Phenomenon in Financial Time Series.

Cyprian Kozyra, Beata Zmyślona, Katarzyna Madziarska: Complementary Objective and Subjective Measures of Hospital Services Quality...

Pavol Král', Mária Stachová, Lukáš Sobíšek: Utilization of Repeatedly Measured Financial Ratios in Corporate Financial Distress Prediction in Slovakia

Ivana Malá: The Use of Finite Mixture Model for Describing Differences in Unemployment Duration

Lukáš Malec: Studying Economics and Tourism Industry Relations by Smooth Partial Least Squares Method Depending on Parameter. 
Tomáš Marcinko: Consequences of Assumption Violations Regarding Classical Location Tests.

Edyta Mazurek: The Income Tax Progression Depending on Social Insurance Contribution in Poland.

Petr Musil, Jana Kramulová, Jan Zeman: Regional Consumption Expenditures: An Important Starting Point for Regional Input-output Tables.

Katarzyna Ostasiewicz, Walenty Ostasiewicz: Good Life: From Political to Human Economy

Anna Sączewska-Piotrowska: Analysis of Poverty Transitions in Poland Using Multilevel Discrete-Time Event History Models

Martina Šimková, Petra Švarcová: Disadvantaged University Students in the Czech Republic.

Michal Široký: The Use of Short-term Business Statistics for Quarterly GDP Flash Estimates in the Czech Republic

Zdeněk Šulc, Hana Řezanková: Evaluation of Recent Similarity Measures for Categorical Data.

Lucia Švábová, Marek Ďurica: The Relationship Between the Finite Difference Method and Trinomial Trees

Kristýna Vltavská, Jaroslav Sixta: The Estimation of Final Consumption Expenditures

Lenka Vraná: Business Cycle Analysis: Tracking Turning Points

Janusz Wywiał: On Bayesian Testing in Auditing

Emília Zimková: Window Analysis of Supper-efficiency Change: Case of the Slovak Banking System ....

Beata Zmyślona: Statistical Modelling of the Impact of Diabetes on the Risk of Hospitalization 


\title{
STUDYING ECONOMICS AND TOURISM INDUSTRY RELATIONS BY SMOOTH PARTIAL LEAST SQUARES METHOD DEPENDING ON PARAMETER
}

\author{
LUKÁS̆ MALEC \\ University of Business in Prague, Department of Information Technologies and Analytical Methods, \\ Spálená 76/14, 110 00, Prague 1 - New Town, Czech Republic \\ email: Lukas.Malec@vso-praha.eu
}

\begin{abstract}
This study deals with two-set statistical method of partial least squares (of its specific form abbreviated as PLS-SVD) and its generalization to the smooth form of this technique using the time parameter. In such an arrangement, the one set can be studied in the time lag considering the other set. The mathematical background dealing with smooth processes of eigenvalues and eigenvectors is included as a consequence of implicit function theorem. The set of five selected economic indicators and the set of three tourism indicators, which are applied to the Czech Republic vs. Poland countries, serve as practical examples. The fundamental year scale of worldwide recession and post-recession data is replaced by a cubic spline interpolant. The practical results show quite different spatial and temporal concept in the processes and relations considering both countries. It seems that the Czech Republic processes are lagged in relations due to the composition of guests and the economic parameters be linked only to the country studied. The economic indicators influence tourism in some sense contrary in both countries.
\end{abstract}

Key words: multivariate analysis, partial least squares, smooth function, tourism.

DOI: $10.15611 /$ amse.2014.17.19

\section{Introduction}

Tourism industry is a very important part of the economy which is generally influenced in global scale, but also by various conditions provided by the individual territory. According to the Tourism Satellite Account methodology, tourism and connected activities plays an important role in direct impact on gross domestic product and employment for most of the European countries. The economic parameters act in many directions. They especially influence per-capita tourism expenditure, number of arrivals and overnight stay decisions. Also, the relations are very complicated due to the global events such as worldwide recession (years 2008 and 2009) and consequent economic growth which also lead to competition between destinations. The worldwide recession and its consequences are particularly affecting the visits of international tourists, especially contributing to national economies. The fall in international tourism arrivals was registered in second half of 2008 resulting worldwide in an only $2 \%$ increase for the year (World Tourism Organization) followed by $4 \%$ decrease in 2009. The 2009 events are also intensified due to the outbreak of the H1N1 influenza virus. Till now, the tourism sector is recovering from the late-2000s recession.

Due to phenomenal growth of tourism demand over the past two decades the research and consequently the number of publications growth on this topic. The research methods include time series models, econometric approaches as well as emerging new parametric and non- 
parametric techniques. Good summary of modelling and forecasting techniques in tourism is published by Song and Li (2008). Presently, the very promising approach to compare economic time series is the cointegration; e.g. in the study of Savas et al. (2010), the relation of volume of international tourism and real exchange rate to economic growth is revealed.

In tourism, PLS-like methods are almost exclusively applied in its special form called structural equation modelling (PLS path modelling) as Prud'homme and Raymond (2013). Our task can be interpreted by the partial least squares method, more specifically of its special form called robust canonical analysis, canonical covariance or intercorrelations analysis and abbreviated as PLS-SVD. Good theoretical background of this method is described in (De Bie et al., 2005; Wegelin, 2000; Lorber et al., 1987). In the context of two data sets, such method searches for a linear system of variables from the first set and a linear system of variables from the second set that captures maximal relations (covariances) between those sets. PLS (PLS-SVD) technique is especially useful in cases of rank-deficient data (when the number of variables exceeds the number of observations) and in case of the collinearity or near collinearity within sets which in variety of known regression methods produces instability of algorithm and misleading interpretation of results. The extension of PLS-SVD method to smooth process depending on time parameter is incorporated in this study. The corresponding theory is presented in link with the well-known process of eigenvalues spectrum over time employing the one-set correlation matrix.

As the areas of interest, the Czech Republic and Poland countries, placed in the Central Europe, were chosen and mutually compared. Excluding the history of both countries, they are currently more associated in some areas. Poland, as well as the Czech Republic, entered EU in 2004, although they keep their own currencies, i.e. Polish zloty and Czech koruna, respectively. Both are presently members of the Visegrad Group, an alliance for the purposes of European integration efforts and advancing their cooperation with one another. From the tourism point of view, the Czech Republic is more concentrated on international tourism.

The economy (business) cycles are often considered as lagged to the tourism (see e.g. Guizzardi and Mazzocchi, 2010). This study in some sense confirms such assumption and is arranged to examine the influence of economic parameters during the worldwide recession and post-recession period on national and international tourism and their ratios. The economic variables are considered only as the country-specific parameters acting in constant points of time to each other and they are arranged in the way to express the conditions for consequent potential tourism interest. The data are examined in both countries as the separate analyses. The key question of this study is to find the lag in time series given by maximum eigenvalue of smooth PLS method and study in which way the economic parameters influence the tourism industry, especially in the points of such maxima.

\section{Experimental}

\subsection{Database studied}

In this study, the annual time series data covering 2006 - 2010 (inclusive) economics and 2006 - 2012 (inclusive) tourism parameters (individual variables) are investigated in the Czech Republic and Poland by using Eurostat database. The five economic indicators include the gross domestic product at market prices (at current prices) in EUR, exchange rates (EUR) vs. national currencies, consumer prices (harmonized indices of consumer prices - annual average indices), real adjusted gross disposable income of households (EUR, households and non-profit institutions serving households) and unemployment rate; the three tourism indicators are total 
number of arrivals in tourist accommodation establishments, the non-residents/residents ratio in arrivals and nights spent at tourist accommodation establishments. ${ }^{1}$ Those variables are from the range of which often used in tourism demand functions together with the arrivals and overnight stays parameters (Lim, 1997). The Eurostat gathers the data from the national statistical offices and promotes the harmonization of statistical methods over its member states, candidates for accession and European free trade association countries.

\subsection{Methods}

The reason why to choose PLS method are strong linear within-set relations, i.e. strong similarity of within-set profiles in our case which means an unambiguous disruption of the input assumptions of other well-known methods such as the canonical correlation analysis, (see Krzanowski, 2000, p. 436). Moreover, we are interested in the covariances rather than the differences between the sets as followed by two-set linear discriminant analysis (although the close connection of PLS to discriminant analysis exists, see e.g. Barker and Rayens, 2003) and number of non-parametric techniques dealing with such a type of problem. The time processes of eigenvalues and corresponding eigenvectors are specific in natural sciences, especially in theoretical physics although in branch of financial time series this approach is also applied (Fricke, 2012; Conlon et al., 2009). In such areas, the eigenvalue spectrum over time is studied on the one-set correlation matrices that means (after considering the inputs as smooth functions) finding the processes of method known as principal component analysis. In this study is performed the smooth processes of eigenvalues and eigenvectors of the betweenset correlation matrix (PLS method) which procedure can easily be extended from one-set correlation matrix. Due to straightforward theory, we concentrate our attention on the time processes of the leading eigenvalue describing our data, and the corresponding eigenvectors. The fundamental year scale in data is replaced by piecewise polynomial form of the cubic spline interpolant providing the second derivative continuous. Because the preceding data exists, the cubic spline interpolation was started one year before the entry to the analyses in our study, i.e. the spline is processed from the year 2005 .

The algorithm is written by the author using MATLAB 7.1 (Mathworks, Natick, MA, USA) software platform. The source code is available on request. The singular value decomposition built-in function is used in the process of the algorithm.

\section{Smooth PLS by parameter}

Let introduce the two sets of smooth functions (of class $\left.C^{(1)}\right)$, i.e. $\left(x_{1}(t), x_{2}(t), \ldots, x_{r}(t)\right)$, $t \in\left\langle t_{1}, t_{k}\right\rangle$ and $\left(y_{1}(t), y_{2}(t), \ldots, y_{s}(t)\right), t \in\left\langle t_{1}, t_{k}+t_{0}\right\rangle$. Next we introduce $\delta \in\left\langle 0, t_{0}\right\rangle$; the times in interval $\left\langle t_{1}, t_{k}\right\rangle$ are chosen in discrete points equidistantly. We mark the matrices

$$
X=\left(\begin{array}{ccc}
x_{1}\left(t_{1}\right) & \cdots & x_{r}\left(t_{1}\right) \\
\vdots & & \vdots \\
x_{1}\left(t_{k}\right) & \cdots & x_{r}\left(t_{k}\right)
\end{array}\right) \text { and } Y(\delta)=\left(\begin{array}{ccc}
y_{1}\left(t_{1}+\delta\right) & \cdots & y_{s}\left(t_{1}+\delta\right) \\
\vdots & & \vdots \\
y_{1}\left(t_{k}+\delta\right) & \cdots & y_{s}\left(t_{k}+\delta\right)
\end{array}\right)
$$

\footnotetext{
${ }^{1}$ The parameters are abbreviated as follows: GDP - gross domestic product, EXCHR - exchange rates, CPRI consumer prices, INC - incomes, UNEMP - unemployment, TARR - total number of arrivals, NR/R - nonresidents and residents arrivals ratio and NIGHT - nights spent.
} 


\section{APPLICATIONS OF

of types $(k, r)$ and $(k, s)$, respectively. The matrix $Y(\delta)$ is dependent on parameter $\delta$ and its elements are also smooth functions.

We consider the matrices $X$ and $Y(\delta)$ as standardized by variables, i.e. in the columnstandardized form. In such a case, our task can be interpreted by the partial least squares method, more specifically of its special form called robust canonical analysis, canonical covariance or intercorrelations analysis and abbreviated PLS-SVD (Wegelin, 2000; De Bie et al., 2005) by generalization to smooth form of this technique using parameter $\delta$. We define this specific problem as

$$
\begin{aligned}
& \max _{\boldsymbol{o} \neq \boldsymbol{u}(\delta) \in R^{r}, \boldsymbol{0} \neq \boldsymbol{v}(\delta) \in R^{s}} \boldsymbol{u}^{\prime}(\delta) X^{\prime} Y(\delta) \boldsymbol{v}(\delta) \\
& \text { s.t. } \boldsymbol{u}^{\prime}(\delta) \boldsymbol{u}(\delta)=\boldsymbol{v}^{\prime}(\delta) \boldsymbol{v}(\delta)=1 .
\end{aligned}
$$

The solution of optimization task (1) for every $\delta$ is realized by the leading singular value $\sigma_{1}(\delta)$ and corresponding singular vectors $\boldsymbol{u}_{1}(\delta)$ and $\boldsymbol{v}_{1}(\delta)$. The leading singular value $\sigma_{1}(\delta)$ equals the maximum value of (1), thus of generalized system

$$
\left(\begin{array}{cc}
0 & X^{\prime} Y(\delta) \\
Y^{\prime}(\delta) X & 0
\end{array}\right)\left(\begin{array}{l}
\boldsymbol{u}(\delta) \\
\boldsymbol{v}(\delta)
\end{array}\right)=\sigma(\delta)\left(\begin{array}{l}
\boldsymbol{u}(\delta) \\
\boldsymbol{v}(\delta)
\end{array}\right),
$$

which is the task for finding singular value decomposition of matrix $X^{\prime} Y(\delta)$ (Golub and Van Loan, 1996, p. 70; Wegelin, 2000).

In the following, we show that vector $\left(\sigma_{1}(\delta), \boldsymbol{u}_{1}(\delta), \boldsymbol{v}_{1}(\delta)\right)$ is smooth function of parameter $\delta$ as a consequence of implicit function theorem. The equation (2) is equivalent to system

$$
\begin{aligned}
& X^{\prime} Y(\delta) Y^{\prime}(\delta) X \boldsymbol{u}(\delta)=\sigma^{2}(\delta) \boldsymbol{u}(\delta) \\
& Y^{\prime}(\delta) X X^{\prime} Y(\delta) \boldsymbol{v}(\delta)=\sigma^{2}(\delta) \boldsymbol{v}(\delta),
\end{aligned}
$$

thus task of finding eigenvalues and corresponding eigenvectors of symmetrical matrices.

As a consequence of the theorem 21.15.1 of Harville (1997), p. 564, which has a local character, we conclude the following statement. If the leading eigenvalue $\sigma_{1}^{2}(\delta)$ of system (3) is for all $\delta$ simple (i.e. its multiplicity is 1), than we can choose corresponding eigenvectors $\boldsymbol{u}_{1}(\delta)$ and $\boldsymbol{v}_{1}(\delta)$ in such a way that function

$$
\left(\sigma_{1}^{2}(\delta), \boldsymbol{u}_{1}(\delta), \boldsymbol{v}_{1}(\delta)\right)
$$

is smooth on interval $\langle 0, \delta\rangle$.

Let $\hat{\boldsymbol{u}}_{1}\left(\delta_{0}\right)$ and $\hat{\boldsymbol{v}}_{1}\left(\delta_{0}\right)$ be the eigenvectors of task (3) corresponding to eigenvalue $\sigma_{1}^{2}\left(\delta_{0}\right)$, $\delta_{0} \in\langle 0, \delta\rangle$. If $\boldsymbol{u}_{1}\left(\delta_{0}\right)=\hat{\boldsymbol{u}}_{1}\left(\delta_{0}\right)$ and $\boldsymbol{v}_{1}\left(\delta_{0}\right)=\hat{\boldsymbol{v}}_{1}\left(\delta_{0}\right)$, then (4) is determined unambiguously. ${ }^{2}$ Also is guaranteed that the corresponding own subspaces $\sigma_{1}^{2}(\delta)$ has a dimension 1 .

\footnotetext{
${ }^{2}$ The numerical computation of (4) can be completed by the set (2) using singular value decomposition theory or by (3) using spectral decomposition theory.
} 


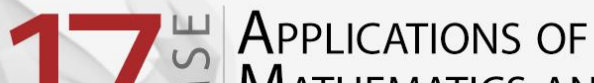 \\ Mathematics and Statistics \\ IN ECONOMICS}

\section{Results and discussion}

By initial inspection of input data is detected that while in the Czech Republic, the ratio of non-residents and residents arrivals is more or less balanced, in Poland the conditions are more favoured to residents as about $78 \%$ of arrivals considers this set. The time processes of singular values are expressed graphically, see Figs. 1 and 2. It is evident that the relation of economic parameters and tourism is lagged in the Czech Republic.

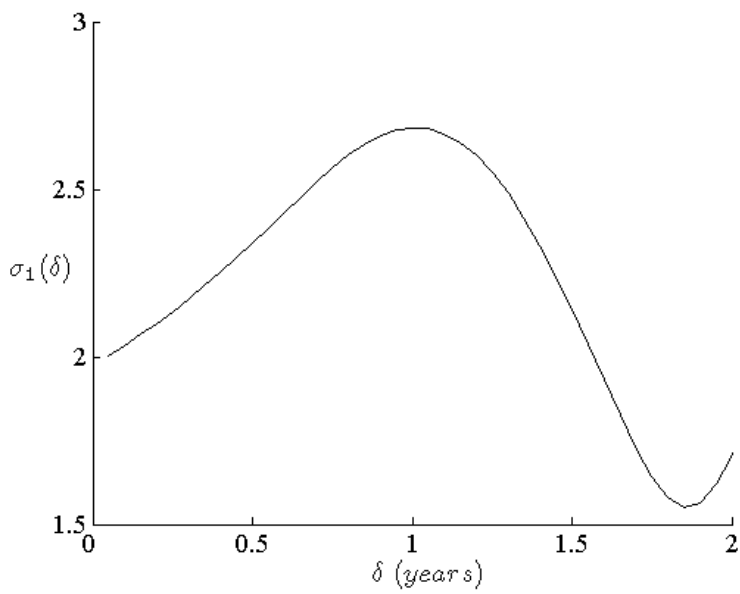

Figure 1. The Czech Republic singular value time process

Source: author

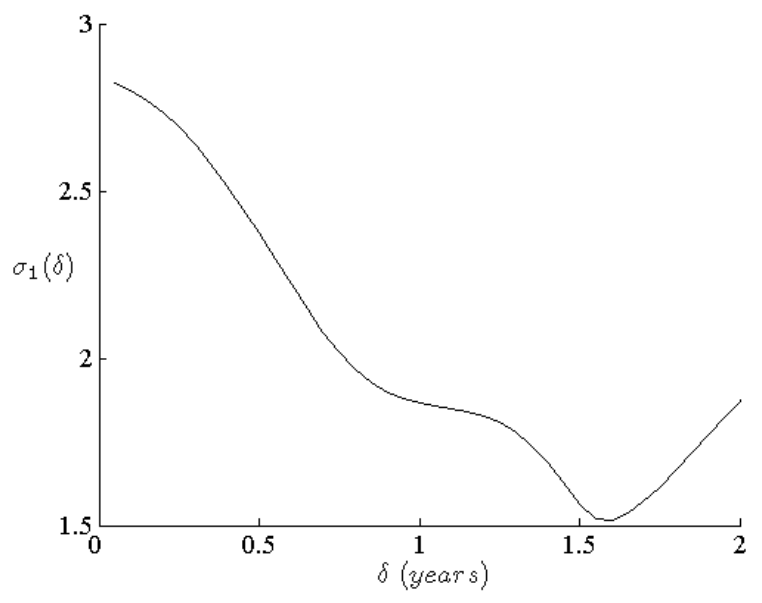

Figure 2. The Poland singular value time process Source: author

Dealing with the Czech Republic, the most related outcomes of first-order smooth PLS method considering both sets and our time interval 2006 - 2012 (inclusive) are for time lag almost one year as having maximum singular value approximately equal to 2.7 . We can see from Table 1 that the relations of economic and tourism parameters with such a lag in economy are characterized by similar processes of non-residents arrivals favouring ratio, total number of arrivals and nights spent and exchange rates parameter opposite to gross domestic product and consumer prices. This is in agreement with the theory as forming ideal conditions for international tourism. Note that the relation of non-residents and residents arrivals ratio is not valid without time lag in economic parameters. This is in accordance with often considered economic lag given e.g. by Savas et al. (2010), probably due to elasticity in price and incomes. Also the unemployment rate is important without time lag as acts opposite to arrivals and nights spent.

The composition of guests (with prevalent share of residents) in Poland differs in comparison to the Czech Republic. Obviously due to this reason the maximum relation between economic parameters and tourism industry is detected without time lag. Also the relations between sets are highly different to the Czech Republic. The processes of resident arrivals (in the ratio of non-residents and residents arrivals), total number of arrivals and nights spent act similarly to gross domestic product and incomes opposite to unemployment rate. The economic parameters are set up to form residents-like conditions in Poland. Contrary, the composition of guests acts in the same direction on the selected economic parameters. Note that from the coefficients of the analysis considering one year lag in Poland is also evident the influence of international tourism although it does not significantly contribute to the total interrelations (unpublished). 


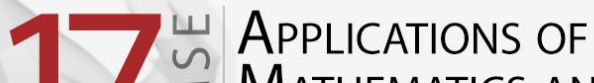 \\ Mathematics and Statistics \\ IN ECONOMICS}

International Scientific Conference | Poland • 27-31 August 2014

Table 1. PLS coefficients

\begin{tabular}{|l|l|l|l|l|l|l|l|}
\hline GDP & EXCHR & CPRI & INC & UNEMP & TARR & NR/R & NIGHT \\
\hline \hline Czech Republic: $\delta=0{ }^{*} \sigma(\delta) \doteq 2.0$ \\
\hline-0.348 & 0.362 & -0.570 & -0.515 & -0.396 & 0.611 & -0.026 & 0.792 \\
\hline Czech Republic: $\delta \doteq 0.95 ; \sigma(\delta) \doteq 2.7$ \\
\hline-0.507 & 0.504 & -0.446 & -0.471 & 0.261 & 0.618 & 0.380 & 0.688 \\
\hline Poland: $\delta=0 ; \sigma(\delta) \doteq 2.8$ \\
\hline-0.502 & -0.031 & -0.471 & -0.510 & 0.515 & -0.580 & 0.558 & -0.594 \\
\hline
\end{tabular}

Source: author

* Time lag is introduced in years.

It is evident from all analyses performed (see Table 1) that the night spent parameter is more linked to economic parameters than the fundamental and well used arrivals of guests. This variable covers in addition to arrival information also economics contribution in the form of length of stay. Note that it is possible that the systems of leading eigenvalues prove more extremas in the process. This study describes the first of them with time interval starting with no lag. Also note that in addition to cubic spline interpolant, the use of piecewise cubic Hermite interpolating polynomial applied to yearly scaled data gives almost identical results in our particular case.

\section{Conclusion}

The PLS method and its extension to smooth form prove its very high usefulness in our specific data processing situation and can serve as a useful tool for policy-makers and the whole range of tourism industry. In such an arrangement, the relations can be studied in maximum point of leading eigenvalue (corresponding to maximum relations) as a time process. The Czech Republic vs. Poland countries were selected as practical examples. While in Poland, the economics and tourism industry relations act in the same moment, the Czech Republic relations are considered with almost one year lag considering our time interval. This is particularly due to the composition of guests with predominant share of residents in Poland. The Czech Republic demonstrates in lagged data positive relation of non-residents share of arrivals, total arrivals and night spent with exchange rates opposite to gross domestic product and consumer prices. Those are typical favouring conditions for non-residents. Contrary, in Poland the residents share of arrivals, total arrivals and nights spent prove similar process (profiles) with gross domestic product and incomes contrary to unemployment forming the typical conditions for resident tourism.

It also was proved, the nights spent is more quality parameter in comparison to arrivals dealing with relation to the selected economic parameters. It is recommended using the parameter nights spent for future analyses covering its link to economy.

\section{Acknowledgements}

The author wishes to acknowledge the financial support of the University of Business in Prague internal grant FRV No. 3/2013. 


\section{References}

1. BARKER, M., RAYENS, W.S. 2003. Partial least squares for discrimination. Journal of Chemometrics, vol. 17, iss. 3, pp. 166-73. ISSN: 1099-128X.

2. CONLON, T., RUSKIN, H.J., CRANE, M. 2009. Cross-correlation dynamics in financial time series. PHYSICA A 388, Elsevier Science B.V., Amsterdam, vol. 5, pp. 705-14. ISSN: 0378-4371.

3. DE BIE, T., CRISTIANINI, N., ROSIPAL, R. 2005. Eigenproblems in pattern recognition. In BAYRO-CORROCHANO, E. (ed.) Handbook of geometric computing: Applications in pattern recognition, computer vision, neural computing, and robotics (pp. 1-39). Heidelberg: Springer-Verlag. ISBN: 978-3-540-20595-1.

4. FRICKE, D. 2012. Trading strategies in the overnight money market: Correlations and clustering on the e-MID trading platform. PHYSICA A 391, Elsevier Science B.V., vol. 24, pp. 6528-42. ISSN: 0378-4371.

5. GOLUB, G.H., VAN LOAN, C.F. 1996. Matrix computations (3rd ed.). Baltimore: The Johns Hopkins University Press. ISBN: 978-0-8018-5414-8.

6. GUIZZARDI, A., MAZZOCCHI, M. 2010. Tourism demand for Italy and the business cycle. Tourism Management, vol. 31, pp. 367-77. ISSN: 0261-5177.

7. HARVILLE, D.A. 1997. Matrix algebra from a statistician's perspective. NY: SpringerVerlag. ISBN: 978-0-387-22677-4.

8. KRZANOWSKI, W.J. (2000). Principles of multivariate analysis: A user's perspective (2nd ed.). Oxford: University Press. ISBN: 978-0-19-850708-6.

9. LIM, C. 1997. Review of international tourism demand models. Annals of Tourism Research, vol. 24, iss. 4, pp. 835-49. ISSN: 0160-7383.

10. LORBER, A., WANGEN, L., KOWALSKI, B. 1987. A theoretical foundation for the PLS algorithm. Journal of Chemometrics, vol. 1, iss. 9, pp. 19-31. ISSN: 1099-128X.

11. PRUD'HOMME, B., RAYMOND, L. 2013. Sustainable development practices in the hospitality industry: An empirical study of their impact on customer satisfaction and intentions. International Journal of Hospitality Management, vol. 34, pp. 116-26. ISSN: 0278-4319.

12. SAVAS, B., BESKAYA, A., SAMILOGLU, F. 2010. Analyzing the impact of international tourism on economic growth in Turkey. ZKU Journal of Social Sciences, vol. 6 , iss. 12 , pp. 121-36. ISSN: 1303-9245.

13. SONG, H., LI, G. 2008. Tourism demand modelling and forecasting - A review of recent research. Tourism Management, vol. 29, pp. 303-20. ISSN: 0261-5177.

14. WEGELIN, J.A. 2000. A survey of partial least squares (PLS) methods, with emphasis on two-block case. Seattle, US, Technical Report 371: University of Washington.

15. WORLD TOURISM ORGANIZATION. 2009. International tourism challenged by deteriorating global economy. UNWTO World Tourism Barometer, January 2009. 